\title{
Zoonotic Bacteria in Fleas Parasitizing Common Voles, Northwestern Spain
}

\section{Ruth Rodríguez-Pastor, ${ }^{1}$ François Mougeot, $M^{\mathrm{a}}$ Dolors Vidal, Isabel Jado, Rosa M. González-Martín-Niño, Raquel Escudero, ${ }^{2}$ Juan José Luque-Larena ${ }^{2}$}

Author affiliations: Universidad de Valladolid and Instituto Universitario de Investigación en Gestión Forestal Sostenible, Palencia, Spain (R. Rodríguez-Pastor, J.J. Luque-Larena); Instituto de Investigación en Recursos Cinegéticos, Ciudad Real, Spain (F. Mougeot); Universidad de Castilla-La Mancha, Ciudad Real (M.D. Vidal); Instituto de Salud Carlos III, Madrid, Spain (I. Jado, R.M. González-Martín-Niño, R. Escudero)

DOI: https://doi.org/10.3201/eid2507.181646

We detected Francisella tularensis and Bartonella spp. in fleas parasitizing common voles (Microtus arvalis) from northwestern Spain; mean prevalence was $6.1 \%$ for $F$. tularensis and $51 \%$ for Bartonella spp. Contrasted vector-host associations in the prevalence of these bacteria suggest that fleas have distinct roles in the transmission cycle of each pathogen in nature.

\footnotetext{
$\mathrm{A}$ dynamic prevalence of Francisella tularensis and Bartonella spp. was reported in irruptive common vole (Microtus arvalis) populations during 2013-2015 from agricultural landscapes of northwestern Spain $(1,2)$. In that area, notifiable tularemia has been endemic since 1997, and human cases periodically occur during outbreaks in voles $(3,4)$. Prevalence of $F$. tularensis and Bartonella spp. in voles increases with vole density $(1,2)$, highlighting the key role of fluctuating rodents in shaping zoonoses dynamics $(1-4)$. Rodent ectoparasites often play a major role in transmitting zoonotic pathogens. In the population studied, ticks rarely infest voles ( $2 \%$ prevalence), whereas fleas are much more prevalent (68\%) (2). Nevertheless, any potential role for vole fleas in the circulation of $F$. tularensis or Bartonella spp. in natural environments remains unknown. To elucidate realistic transmission route scenarios in hostdynamic environments $(5-8)$, we investigated whether zoonotic bacteria occur concomitantly in voles and fleas.

Our main goal was to study the prevalence of F. tularensis in fleas collected from voles previously tested for tularemia (1). We screened flea DNA in search of 6 main

${ }^{1}$ Current affiliation: Ben-Gurion University of the Negev, Midreshet Ben-Gurion, Israel.

${ }^{2}$ These authors contributed equally to this article.
}

zoonotic bacteria simultaneously (Anaplasma phagocytophilum, Bartonella spp., Borrelia spp., Coxiella burnetii, F. tularensis, and Rickettsia spp.), following the same molecular procedure (multiplex PCR) (9) previously used to screen vole pathogens $(1,2)$. Voles and fleas were live-trapped in northwestern Spain during March 2013-March 2015 (Appendix, https://wwwnc.cdc.gov/EID/article/25/7/18-1646App1.pdf). We collected fleas from each individual vole and identified and grouped them in pools (pool = total fleas/ vole). Three flea species parasitize common voles in the area: Ctenophthalmus apertus, Nosopsyllus fasciatus, and Leptopsylla taschenbergi (2). We screened monospecific pools (all fleas in a pool belonged to the same species and came from the same vole host), for a sample size of 90 vole hosts (pools) and 191 fleas. We screened 78 C. apertus fleas (39 pools) and $113 \mathrm{~N}$. fasciatus fleas (51 pools). Among the 90 voles providing fleas, 27 were $F$. tularensis PCRpositive; the remaining 63 were negative (1). Of these same 90 voles, 45 were Bartonella PCR-positive and 45 were negative. Seventeen were positive for both $F$. tularensis and Bartonella spp. (2).

Flea pools had an average of 2.12 fleas (range 1-9); however, most $(>70 \%)$ contained $1(51 \%)$ or $2(22 \%)$ fleas (Table). We did not detect DNA from pathogens other than F. tularensis and Bartonella spp. in fleas. Three (3\%) flea pools harbored $F$. tularensis DNA; we estimated the overall prevalence at $6 \%$. F. tularensis prevalence in both flea species was low (1 positive pool of 51 in $N$. fasciatus and 2 of 39 in C. apertus). All F. tularensis PCR-positive flea pools came from $F$. tularensis PCR-positive voles, and prevalence of $F$. tularensis in fleas was significantly associated with its prevalence in voles (analysis of variance [ANOVA], $\mathrm{R}^{2}=0.072, \mathrm{~F}_{0.05,1,88}=6.81 ; \mathrm{p}=0.011$ ). Of note, all fleas containing $F$. tularensis DNA were collected during July 2014, when vole populations reached top densities and tularemia prevalence peaked among them (33\%) (1). The low prevalence of $F$. tularensis detected in fleas carried by infected hosts ( 3 of 27 pools) and the detection of infected flea pools only when abundance of the bacterium in the environment was highest (during vole peaks) $(1,4)$ suggest that the quantitative role of fleas in the circulation of $F$. tularensis might be modest.

Conversely, the role of fleas in the circulation of Bartonella spp. seems much more relevant. We detected Bartonella spp. in 28 (37\%) flea pools and in both flea species (37\% of $N$. fasciatus and $23 \%$ of C. apertus) (Table). We detected Bartonella spp. in fleas collected from Bartonella PCR-positive and Bartonella PCR-negative voles in nearly equal proportions ( $51 \%$ vs. $44 \%$ ) (Table). The average prevalence of Bartonella spp. in fleas was not associated with its prevalence in voles (ANOVA, $\mathrm{R}^{2}=0.006, \mathrm{~F}_{0.05,1,88}$ $=0.53 ; \mathrm{p}=0.467)$. We found a higher Bartonella spp. prevalence in $N$. fasciatus $(65 \%)$ than in C. apertus $(33 \%)$. 
Table. Detection of Francisella tularensis and Bartonella spp. in 2 species of fleas from live common voles (Microtus arvalis), northwestern Spain, 2013-2015*

\begin{tabular}{|c|c|c|c|c|c|c|c|}
\hline \multirow[b]{2}{*}{ Voles } & \multirow[b]{2}{*}{ Flea species } & \multicolumn{3}{|c|}{ Flea pools } & \multicolumn{3}{|c|}{ Fleas } \\
\hline & & No. & $\begin{array}{c}F . \\
\text { tularensis- } \\
\text { positive, } \%\end{array}$ & $\begin{array}{l}\text { Bartonella } \\
\text { spp.- } \\
\text { positive, \% }\end{array}$ & No. & $\begin{array}{l}\text { F. tularensis } \\
\text { prevalence, \% } \\
\text { (range) }\end{array}$ & $\begin{array}{l}\text { Bartonella spp. } \\
\text { prevalence, \% } \\
\text { (range) }\end{array}$ \\
\hline \multirow[t]{3}{*}{ All } & All & 90 & 3.3 & 31.1 & 191 & $6.1(3.3-8.8)$ & $51.1([31.1-71.1)$ \\
\hline & Nosopsyllus fasciatus & 51 & 2.6 & 37.3 & 113 & $6.9(3.9-9.8)$ & 64.7 (37.3-92.2) \\
\hline & Ctenophthalmus apertus & 39 & 3.9 & 23.1 & 78 & $5.1(2.6-7.7)$ & $33.3(23.1-43.6)$ \\
\hline \multirow[t]{3}{*}{ F. tularensis-negative } & All & 63 & & & 127 & 0 & \\
\hline & N. fasciatus & 32 & & & 71 & 0 & \\
\hline & C. apertus & 31 & & & 56 & 0 & \\
\hline \multirow[t]{3}{*}{ F. tularensis-positive } & All & 27 & & & 64 & $20.4(11.1-29.6)$ & \\
\hline & N. fasciatus & 19 & & & 42 & $18.4(10.5-26.3)$ & \\
\hline & C. apertus & 8 & & & 22 & $25.0(12.5-37.5)$ & \\
\hline \multirow{3}{*}{ Bartonella spp.-negative } & All & 45 & & & 93 & & $44.4(26.7-62.2)$ \\
\hline & N. fasciatus & 21 & & & 53 & & $71.4(38.1-100)$ \\
\hline & C. apertus & 24 & & & 40 & & $20.8(16.7-25.0)$ \\
\hline \multirow{3}{*}{ Bartonella spp.-positive } & All & 45 & & & 98 & & $51.1(31.1-71.1)$ \\
\hline & N. fasciatus & 30 & & & 60 & & $60(36.7-83.3)$ \\
\hline & C. apertus & 15 & & & 38 & & 53.3 (33.3-73.3) \\
\hline
\end{tabular}

We identified 3 Bartonella species among fleas (B. taylorii $[17 \%]$, B. grahamii $[14 \%]$, and B. rochalimae [3\%]), as well as mixed infections (Appendix). These findings are in accordance with other research showing fleas as a main vector of Bartonella spp. (5). Although F. tularensis and Bartonella spp. have been simultaneously detected in $\approx 13 \%$ of voles during population density peaks (2), we identified no co-infection among flea pools (ANOVA, $\mathrm{R}^{2}=0.011$, $\mathrm{F}_{0.05,1,88}=0.97 ; \mathrm{p}=0.328$ ).

Our data show that F. tularensis and Bartonella spp. occur in the fleas infesting wild common voles in northwestern Spain, with notable differences in prevalence $(6 \%$ and $51 \%$, respectively) and associations with prevalence in vole hosts. Future studies are needed to determine the role of fleas in the circulation of these pathogens in nature and in particular to ascertain any effective vectoring of F. tularensis.

\section{Acknowledgments}

We thank Fabio Flechoso for helping with ectoparasite counts and flea identification.

This work was supported by ECOVOLE (Factores ecologicos que influyen en la reproducción y dinámica poblacional del topillo campesino (Microtus arvalis) en medios agrarios; CGL2012-35348), ECOTULA (Ecología de la Tularemia: dinámica espacio-temporal, ciclos ecológicos de transmisión y mapas de riesgo en ecosistemas agrarios del NO de España; CGL2015-66962-C2-1-R), and RESERTULA (Microbiología de la Tularemia: circulación de Francisella tularensis en los ecosistemas agrarios del NO de España. Estudio d relaciones epidemiológicas y filogenéticas; CLG2015-66962-C2-2-R) projects funded by the Government of Spain (IMINECO/FEDER). R.R.-P. was supported by a $\mathrm{PhD}$ studentship from the University of Valladolid (co-funded by Banco Santander, RR 30/04/2014).

\section{About the Author}

Dr. Rodríguez-Pastor is a postdoctoral student at the Mitrani Department of Desert Ecology, Jacob Blaustein Institutes for Desert Research, Ben-Gurion University of the Negev, Midreshet Ben-Gurion, Israel. Her research interests include the ecology of zoonoses and disease dynamics in animal populations, specifically parasite and infectious pathogen dynamics in wild rodents.

\section{References}

1. Rodríguez-Pastor R, Escudero R, Vidal D, Mougeot F, Arroyo B, Lambin X, et al. Density-dependent prevalence of Francisella tularensis in fluctuating vole populations, northwestern Spain. Emerg Infect Dis. 2017;23:1377-9. http://dx.doi.org/10.3201/ eid2308.161194

2. Rodríguez-Pastor R, Escudero R, Lambin X, Vidal MD, Gil H, Jado I, et al. Zoonotic pathogens in fluctuating common vole (Microtus arvalis) populations: occurrence and dynamics. Parasitology. 2019;146:389-98.

3. Luque-Larena JJ, Mougeot F, Roig DV, Lambin X, Rodríguez-Pastor R, Rodríguez-Valín E, et al. Tularemia outbreaks and common vole (Microtus arvalis) irruptive population dynamics in northwestern Spain, 1997-2014. Vector Borne Zoonotic Dis. 2015;15:568-70. http://dx.doi.org/10.1089/ vbz.2015.1770

4. Luque-Larena JJ, Mougeot F, Arroyo B, Vidal MD, Rodríguez-Pastor R, Escudero R, et al. Irruptive mammal host populations shape tularemia epidemiology. PLoS Pathog. 2017;13:e1006622. http://dx.doi.org/10.1371/journal.ppat.1006622

5. Gutiérrez R, Krasnov B, Morick D, Gottlieb Y, Khokhlova IS, Harrus S. Bartonella infection in rodents and their flea ectoparasites: an overview. Vector Borne Zoonotic Dis. 2015;15:27-39. http://dx.doi.org/10.1089/vbz.2014.1606

6. Silaghi C, Pfeffer M, Kiefer D, Kiefer M, Obiegala A. Bartonella, rodents, fleas and ticks: a molecular field study on hostvector-pathogen associations in Saxony, eastern Germany. Microb Ecol. 2016;72:965-74. http://dx.doi.org/10.1007 /s00248-016-0787-8

7. Hornok S, Földvári G, Rigó K, Meli ML, Gönczi E, Répási A, et al. Synanthropic rodents and their ectoparasites as carriers 
of a novel haemoplasma and vector-borne, zoonotic pathogens indoors. Parasit Vectors. 2015;8:27. http://dx.doi.org/10.1186/ s13071-014-0630-3

8. Stevenson HL, Bai Y, Kosoy MY, Montenieri JA, Lowell JL, Chu MC, et al. Detection of novel Bartonella strains and Yersinia pestis in prairie dogs and their fleas (Siphonaptera: Ceratophyllidae and Pulicidae) using multiplex polymerase chain reaction. J Med Entomol. 2003;40:329-37. http://dx.doi.org/10.1603/ 0022-2585-40.3.329

9. Anda P, Escudero R, Rodriguez-Moreno I, Jado I, Jimenez-Alonso MI. Method and kit for the detection of bacterial species by means of DNA analysis. European patent EP1895015B1. 2012 July 25.

Address for correspondence: Ruth Rodríguez-Pastor, Mitrani Department of Desert Ecology, Jacob Blaustein Institutes for Desert Research, Ben-Gurion University of the Negev, Midreshet Ben-Gurion, 84990, Israel; email: ruth.r.pastor@gmail.com

\section{Mycobacterium bovis Infection in African Wild Dogs, Kruger National Park, South Africa}

\author{
Roxanne L. Higgitt, O. Louis van Schalkwyk, \\ Lin-Mari de Klerk-Lorist, Peter E. Buss, \\ Peter Caldwell, Leana Rossouw, \\ Tebogo Manamela, Guy A. Hausler, \\ Jennie Hewlett, ${ }^{1}$ Emily P. Mitchell, ${ }^{1}$ \\ Paul D. van Helden, Sven D.C. Parsons, ${ }^{2}$ \\ Michele A. Miller ${ }^{2}$
}

Author affiliations: Stellenbosch University, Cape Town, South Africa (R.L. Higgitt, G.A. Hausler, P.D. van Helden, S.D.C. Parsons, M.A. Miller); Department of Agriculture, Forestry and Fisheries, Skukuza, South Africa (O.L. van Schalkwyk, L.-M. de Klerk-Lorist); South African National Parks, Skukuza (P.E. Buss, L. Rossouw, T. Manamela, J. Hewlett); Old Chapel Veterinary Clinic, Pretoria, South Africa (P. Caldwell); National Zoological Gardens of South Africa, Pretoria (E.P. Mitchell)

DOI: https://doi.org/10.3201/eid2507.181653

${ }^{1}$ Current affiliation: University of Pretoria, Onderstepoort, South Africa.

${ }^{2}$ These authors were co-principal investigators for this article.
We screened African wild dogs (Lycaon pictus) in Kruger National Park, South Africa, for Mycobacterium bovis infection using an interferon-gamma release assay. We detected M. bovis sensitization in 20 of 21 packs; overall apparent infection prevalence was $83 \%$. These animals experience high infection pressure, which may affect long-term survival and conservation strategies.

$\mathrm{T}$ he African wild dog (Lycaon pictus) is an endangered carnivore occurring in fragmented, small populations (in South Africa, $<500$ animals). These factors make them susceptible to adverse factors, such as infectious diseases, that may threaten their long-term survival $(1,2)$. Of particular concern are diseases caused by multihost pathogens that are capable of persisting in reservoir host species, such as Mycobacterium bovis, the causative agent of bovine tuberculosis (bTB). This pathogen may pose a major threat to the conservation of endangered host populations (3).

Since 2012, sporadic cases of wild dogs with macroscopic and histological lesions consistent with tuberculosis (TB) have been recorded in South Africa, specifically in Kruger National Park (KNP; $\mathrm{n}=8$ ), uMkuze Game Reserve $(\mathrm{n}=1)$, and Hluhluwe-iMfolozi Park (HiP; $\mathrm{n}=2)$. $M$. bovis infection is endemic in these parks and occurs in multiple species that are preyed upon by wild dogs, such as warthogs, which have an estimated $M$. bovis seroprevalence up to $38 \%$ in KNP $(4,5)$. In 2 cases from KNP, acid-fast bacilli were associated with granulomatous lymphadenitis, and spoligotype analysis of $M$. bovis isolates from lesions in affected wild dogs from KNP (strain type SB0121) and HiP (strain type SB0130) were the same as those found in local prey (6).

$M$. bovis is a novel pathogen of wild dogs; understanding the impact of bTB disease in wild dogs is imperative to making informed management decisions regarding these animals' conservation. Estimation of prevalence would provide a starting point for this investigation but requires diagnostic tools for accurate detection of $M$. bovis infection. To estimate prevalence in the KNP wild dog population, we assessed sensitization to TB antigens ESAT- 6 and CFP-10.

During July 2016-January 2018, we tested blood samples from 77 wild dogs from KNP using an interferongamma release assay (IGRA) developed by our group (7). We tested animals from 21 wild dog packs; 20 of these included $\geq 1$ IGRA-positive animal, indicating widespread exposure to $M$. bovis throughout KNP (Figure). We observed no significant difference in IGRA results based on sex ( $p=0.79$ by 2 -tailed Mann-Whitney test). Overall, the apparent prevalence of $M$. bovis infection was $82 \%(63 / 77$; $95 \%$ CI $72 \%-89 \%$ by modified Wald test).

Few reports of active bTB disease and related deaths have been documented in wild dogs, so the high apparent 